\title{
Crime against Women and Its Suppression in Punjab during 1861 to 1919: With Special Reference to Female Infanticide, Trafficking of Women, Prostitution and Sati
}

Mandeep Kaur*

Guru Nanak Dev University, Amritsar, India

\begin{abstract}
The condition of women continued to deteriorate from post Vedic period till the Medieval period and it became worst during the advent of British in Punjab. There was nothing which could be said as the rights of women and women empowerment. Many crimes were committed against her. In the present work the crimes of female infanticide, trafficking of women, prostitution and Sati in the province of Punjab have been discussed during 1861 to 1919 , along with the endeavors made by the British in this period to suppress these crimes. The causes which led to the commission of such crimes have been also discussed in this work.
\end{abstract}

Keywords: Women; Crime; Female Infanticide; Trafficking; Prostitution; Sati; Rights; Police; British

\section{Introduction}

The soil of Punjab has been structure of two ancient civilizations; the Indus Valley Civilization and the Vedic Civilization. In both these civilizations the condition of women was very good. In the former she had the status of the mother Goddess and it the later she had equal rights and enjoyed equal status as that was enjoyed by the man. Her position somehow deteriorated in the post Vedic period. In this period some social customs and traditions made adverse impact on the social status of women. Further in the Medieval period, her status ruined to worse than anything. She had been regarded as the footwear of Man "Paer ki Juti". She was given the third class treatment and was often compared with animals and low caste (Shudra). She was exploited in every field of the society. Evils like Sati, women trafficking, female infanticide and feticide, prostitution etc. were practiced. The position of women became such that the reformers of the Bhakti Movement had to come forward in her support. The Sikh Gurus severely criticized these evils. But the position of women remained the same. With the advent of British, during colonial period, the birth of girl child was never regarded as a happy occasion rather the birth of son was celebrated with greetings and joy. The birth of the girl was regarded as the advent of troubles and problems for her parents. She was put to death immediately after her birth to get rid of these alleged troubles and problems. Fortunately, the girls who survived were treated badly. They were not allowed to get education [1] and were taught to learn household work and less time was given to them for sleep and enjoy. The education to women was considered unnecessary, unorthodox and dangerous [2]. She was regarded as other's wealth (Paraya Dhan) so spending money on her education ought to be a shear wastage. The female child was given very simple clothes to wear as compared to the male child [3]. The customs of child marriage and purdah were the main hindrances in women's education [4]. Widow remarriage was not recognized. The attitude of the society towards the widows was inhuman and cruel. The widow remarriage was accepted in the Jat Sikhs of Punjab but the widows were married to the elder or the younger brother of the deceased husband irrespective of the fact that whether he was already married or not. The custom was known as chadar dalana. This made the family affairs shadowy and polygamous [5]. In this miserable condition of the women, when she was regarded as the private property of man and when there was nothing known about the so called rights of women, a number of crimes were committed against women in Punjab. Some of them were female infanticide, Sati, Prostitution, Trafficing in women etc. These have been discussed below:

\section{Female infanticide}

It connoted to the killing of female child. As discussed above, the girl child was not regarded as equal to the boy child. Putting the female child to death after her birth was the most unfortunate practice prevalent in Punjab. During colonial period this practice was widely prevalent among the Khatris, Rajputs, Jats and all the classes of Sikhs [6]. The most of the castes, especially the Rajput of hills, did not commit this crime because they were too proud to give their daughters in marriage, but because they could not afford the traditional marriage expenditure or because they foresaw difficulties in marrying them suitably [7]. The Bedis (the decedents of Guru Nanak) in Punjab were regarded as the daughter slayers (Kurimaar) [8]. Due to annexation, a great deflation had taken place among the Bedis, who were the reliable upholders of this evil. Their priestly pride greatly humiliated, their occupation nearly gone, their sources of revenue speedily vanishing away, there remained nothing to support them against the condemnation of their fellows. It was reported about the Bedis that, "their inherent pride and the supposed sanctity of their order, make the Bedis unwilling to contract alliances for their daughters, who were consequently doomed to an early death [9]. It was a general belief amongst them that their present depressed condition had been the result of disfavor of the Almighty, chiefly brought upon them by the adoption of that very practice [10]. The custom was prevalent among the Sodhis of Ambala, Patiala and Nabha, Jats of Multan, Gujranwala and Jhelum and Muslims of Jhelum and Ferozepur. Among the Sikh Jats, the Sandhus had the reputation of

*Corresponding author: Mandeep Kaur, Research Scholar, Guru Nanak Dev University, Amritsar, India, Tel: +0183 225 8809; E-mail: bagelewala@gmail.com

Received September 23, 2017; Accepted September 30, 2017; Published October 03, 2017

Citation: Kaur M (2017) Crime against Women and Its Suppression in Punjab during 1861 to 1919: With Special Reference to Female Infanticide, Trafficking of Women, Prostitution and Sati. Arts Social Sci J 8: 300. doi: 10.4172/21516200.1000300

Copyright: (c) 2017 Kaur M. This is an open-access article distributed under the terms of the Creative Commons Attribution License, which permits unrestricted use, distribution, and reproduction in any medium, provided the original author and source are credited. 
committing this crime and they had the lowest proportion of females among any class [11]. The crime of female infanticide was committed in variety of ways. The infant was put into an earthen pot (Ghara) and buried alive in the ground. Sometimes, the girl child was given an overdose of opium so that never to rise again. Often the mother's nipples were rubbed with opium or Asclepius gigantean (Madar plant/ akk-milk) and the infant child imbibed poison with the milk [12]. Child's mouth was filled with cow-dung, or his head was submerged in cow's milk, or the umbilical cord was drawn over his face. This prevented respiration and caused immediate death. In Jalandhar, the method reported was starvation followed by a glut of milk. This caused severe colic or exposure to the weather. In Gujrat, the child was buried alive. The Bedis used to went even further in cruelty. After the death of the child, the corpse was taken to a jungle and was made to sit under a tree, jaggery (Gur) was put into her mouth and a corded role of cotton (batti) was placed between her fingers and then a song was sung:

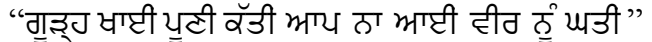

(Eat Jaggery, spin cotton, do not come back yourself, send a brother)

This crime was more prevalent in the district of Jalandhar in 1921. It was said to be more notorious than any other part of the Punjab for indulgence in this practice [13]. Nine villages in the district of Jalandhar where this crime was most suspected had been declared under the Female Infanticide Act, 1870 in 1884. But even then the Lieutenant Governor of Punjab remarked that among certain castes in Jalandhar, Ferozepur and Ludhiana districts, the crime "still prevails to a most lamentable extent [14]. Due to this crime the female population in Punjab was decreased. In 1853 the ratio of female to male children in Kangra district was 87 females for 100 males. In 1881 the report of census was surprising. In Punjab there were 5425 males and 4575 females among every 10,000 of the population [15]. According to the census of 1891, there were only 850 females to every 1000 males in Punjab [16]. In the year 1901 there were 852 females to 1000 males [17]. From these figures it was clear that the girl children were neglected and the form of custom of female infanticide is a matter of more concern than actual murders [18]. For the suppression of the crime of female infanticide, the police hesitated to deal it with directly. It was thought that by direct supervision or secret spying of this crime there would be extortion or oppression [19]. It was thought that persuasive measures should be taken undermining the principle on which this crime was based upon. For this, it was proposed that death penalty should be proclaimed for the persons who commit this crime along with the forfeiture of all jagirs and pensionary allowances of the families committing this crime and on the other hand the persons who were endeavoring towards its suppression should be rewarded. It was also proposed that the marriage expenses should be limited, by common consent and voluntary determination of the people, to such amounts as might do away with all the inducements to or pretext for the secret destruction of female children [20]. There was much discussion on this subject in the meetings of Hindus, Muslims and Sikhs at Jalandhar (16 ${ }^{\text {th }}$ April, 1853) and at Hoshiarpur (16 $6^{\text {th }}$ April, 1853). The Bedis and Rajputs agreed to abide by the resolutions passed in these meetings. A report regarding the resolutions and certain recommendations to check this crime, from all quarters, were sent to the Government of India [21] were approved and a proclamation was issued in the Punjab. Death penalty and the forfeiture of the jagirs and properties along with the pensionary allowances was declared under this proclamation for a person and of the families committing this crime [22]. After this a meeting was held in Amritsar in 1853. It was declared, by the delegates assembled, before the European officers that they would frame certain rules to reduce the marriage expenses, both for rich and poor. No hardship would be felt in arranging the marriage of their daughters and the object or motive behind this crime would become infructuous. The meeting left quiet great and deep positive impression on the minds of the people [23]. After this meeting, local meetings were held at other places. Many families kept the promise which was recorded in these meetings. The Amritsar meeting was regarded as the great epoch in the history of anti-female infanticide movement [24]. Although, all these factors and measures, unnatural parents fearing detection used no means likely to led to conviction, but the infants were either allowed to die from neglects or from inadequate food or exposure which led to virtual infanticide. During the illness of the female child no notice was taken unless the ailment becomes serious. This neglect of female infants was probably the most important cause of the disparity of the sexes [25]. It was a fact that the life of female was less cared for, especially in infancy, than that of males [26]. In the year 1905, it was reported that many Superintendents were not able to differentiate the ordinary murders of children and the true cases of infanticide. According to the reported cases of the murders of children there had been an increase of 45 in the number of the children under the age of 12 years murdered during that year. It can be revealed from the data from the districts that the cases of the murder of children and especially the female children were cases of infanticides although the true cases of infanticide reported never increased [27].

\section{Female Trafficking, Prostitution and Sati}

The crime of trafficking in women was an unusual practice prevalent in the province. The sale or purchase of females like a commodity is such practice which was and is still practiced in almost whole world. The crime was usually connoted as 'barda faroshi' which means practicing the trade of slaves or slave trade. The causes of this evil observed in all countries were poverty and ignorance. But in Punjab, where there was no scarcity of either, it was hardly shocking to see, at some places, morality at its lower level among women. The vital cause of the trafficking of women in Punjab was the shortage of marriageable women which was due to the prevalence of female infanticide in the society. It was reported that there was undoubtedly a scarcity of women in many districts, and so long as this continues the traffic in women will be prevalent [28]. It was published in the newspapers of that time that this was very profitable and flourishing trade [29]. It can be observed that trafficking of women was practiced both for prostitution and for marriage. The later can also be called as bride buying. This practice (especially bride buying) was common among the lower classes, but sometimes the purchasing parties were from higher classes too. It was common in almost whole Punjab that if the male who has sufficient property or earning, due to any other reason could not get married in his class or according to his status, he would purchase any women and marry her. This was also in case if any man could not have had an issue (especially a male issue) from his first wedded wife then he would marry second one or the third. Even after marrying a number of times (as polygamy existed that time and bigamy or polygamy was not regarded as crime) no wife could begot child for him and due to old age no one would give him anymore wife, he would then purchase a woman to get child from her. Although the women who were taken home by this practice were not seen with such respect as would have seen if they would have married otherwise, yet it was practiced only to fulfill the purpose for which they had been purchased for. But if all went well in the new homes of such women and with the passage of time nothing further was heard of and they acquired the 
status and respect of wives and mothers. The consent of the women was impliedly taken or it can be said she was very often a willing party to the transaction. In many cases the women were willing victims and their sale not infrequently involves cheating [30]. In the majority of cases the woman was old enough to know the consequences and willingly consented to forsake a poverty-stricken home for the wealth and comfort to be found in the house of a prosperous Jat Zamindar [31]. Generally, the women were purchased from the same castes but from poverty-stricken homes but there existed the cases too, in which the women were taken from the low castes. In some cases, if the woman was unwilling or did not feel at home in her bridegroom's house or if the bridegroom discovered that she was of lower caste than what she was supposed to be, the matter was likely to come up before the police for investigation [32].The women who were purchased for marriage in Punjab were mostly from Himalayan and mountain districts, whose women were favored of somewhat easy virtue and incredibly ignorant. Women were also imported from the east of the Jamuna. Sometimes the brokers, through whom the women were purchased, were kept under suspicion of selling the women for prostitution. In order to deal with such cases, the administration had instructed the lambardars to report to the police if they consider the presence of any strange woman in their respective village. It was hoped that these instructions would put a check on the trafficking of women for prostitution, but the situation remained unchanged. Sometimes it was discovered that this crime was committed in an organized manner and by the gangs. In many cases fraud was practiced. The woman was sold and shortly afterwards decamped with jewelry which her purchaser had given her and rejoined the man who had sold her. In the year 1892, in Delhi district about 18 agencies for the disposal of women were said to existed [33]. A gang was detected and convicted in Dera Ghazi Khan in the year 1911. In two cases, one of Kangra district in which a Muhammadan Gujar girl was sold to a Brahmin as belonging to his caste for Rs. 1150/and other in which Rs. 300/- were paid, the persons engaged in this occupation usually entailed in abduction and often cheating [34]. The District magistrate of Gurdaspur, Mr. Watson summed up the general situation of this crime by his remarks, "This traffic in women goes on a large scale, and is very difficult to stop. Rajput women from the Pathankot tehsil and low caste women such as Dums, who have joined the Arya Samaj and become 'Mahashais' are passed off as Jats or Rajputs, are the most common articles of commerce [35]. In 1916, another gang of professional traders in women was successfully prosecuted on 14 charges by the police of Multan district. This gang was headed by or the managing agent of the gang was an ex-constable of the United Provinces Police, with his head-quarters at Meerut and sub-agencies at different places in the Multan district. The modusoprendi was to bring the women of low castes from United Provinces to Multan where they were sold to higher caste Hindus in need of wives [36]. This crime was practiced far more extensively than was generally known and apparently continued to be rife in the Multan division and in the Kangra, Hoshiarpur, Lyallpur, Ferozepur, Lahore, Jalandhar, Gurdaspur and Sialkot districts. It was reported that it took the form of the sale of low caste women from poverty-stricken homes to men of higher caste and comparatively comfortable means [37,38]. The women were purchased mostly by Jats (both Hindu and Sikh), Aroras or Kirars, to some degree by Kambohs and Khatris. In Peshawar and Kohat, the women were purchased by Khattaks from Pathans. It was considered that the women who were sold by the Pathans were not faithful and due to this reason instead of being murdered they were sold as a punishment [39]. The women were also sold or purchased for the purpose of prostitution. It was viewed that such women generally belonged to Muslim communities. As regards prostitution among Indian women, they were differentiated as one who embraced the profession in accordance with the dictates of religious beliefs and customs, and the other who followed it as a regular business or means of livelihood. In Punjab they were known by various names such as tawaif, randi etc. and those who practiced the trade secretly were known as khanagis. The custom of taking their girls to this profession was followed by Harnis who were otherwise regarded as professional robbers or thieves. There was increase in the number of prostitutes or the dancing girls since the beginning of the twentieth century [40]. There was a regular trade in women who were peddled from place to place by professional cheats, in Hoshiarpur, Ludhiana and Ambala [41]. The Criminal Investigation Department co-operated with the District Police in investigating and prosecuting the cases of prostitution and it was suggested that the action against the habitual kidnappers and abductors and their abettors under section 110 of Criminal Procedure Code would yield good preventive results [42]. The practice of Sati was another crime committed against women. The third and fifth Gurus of the Sikhs had strongly denounced the practice. Usually Sikh women didn't burn themselves with the corpse of their husbands [43]. But under the Brahmanical influence sometimes the Sikh ladies of higher families did so. When Ranjit Singh died his four principal wives, along with seven slave girls, burnt themselves alive on his funeral pyre [44]. From the time of the Gurus, this was the first recorded event of sati among the Sikhs [45]. Same way when Kharak Singh and Kanwar Nau Nihal Singh died the practice of sati was performed [46]. It seems that Lahore Darbar was not against this practice, but it was rare amongst the common people. The reason for this can be observed that among the Jat Sikhs the custom of chadar or kurawa prevailed under which the widow was remarried to the relative of the deceased (mostly the brother). This custom however, prevailed in the hills among the Hindus. In 1847, Lord Hasting issued a proclamation from Shimla declaring the practice to be stopped forthwith. He asked the rulers of the native states in the Punjab and the alliance with the British to enforce the law as established by the British Government. The abetment of Sati was punishable under the Indian Penal Code [47].

\section{Conclusion}

In 1905, a case of Sati came into light in the district of Karnal and the accused were finally convicted under sections 304 and 309 of the Indian Penal Code [47]. In this way the condition of the women was not good, rather it was worst and among the other atrocities and crimes the above discussed crimes were prevalent in Punjab till the second decade of the starting of the twentieth century. Although the authorities tried through different penal and other legislations to check these crimes yet these crimes continued to exist in one form or the other because the roots of these crimes had rooted deep in the society. The crime of Sati can be regarded as an exception to this as this crime was controlled to much extent by the British authorities.

\section{References}

1. In 1901 the number of literates in the province was 64 males per 1000 or only 3 females per 1000 of the total population. The Punjab comprised of 29 districts and total population of the province was 24367113; Census of India 1910. 1: 160.

2. Census of India 1921. 1: 180

3. Saini BS (1975) The Social and Economic History of Punjab, Ess Publications, Delhi, p: 16.

4. Lajpat Rai (1915) The Arya Samaj, Longman Green \& Co, London, p: 143.

5. Census of India 1911. 14: 282

6. Punjab Census Report 1891; Census of India 1911. 1: 215-219. 
Citation: Kaur M (2017) Crime against Women and Its Suppression in Punjab during 1861 to 1919: With Special Reference to Female Infanticide, Trafficking of Women, Prostitution and Sati. Arts Social Sci J 8: 300. doi: 10.4172/2151-6200.1000300

7. Grant JP (1853) Officiating Secretary to the Government of India to John Lawrence, Chief Commissioner of Punjab, Fort William, $7^{\text {th }}$ September, Foreign Proceedings No, 185-187, $9^{\text {th }}$ September, 1853; Report of the Administration of the Punjab Proper for the year 1849-50 \& 1850-51, p: 65

8. Melville $P$ (1853) Secretary to the Chief Commissioner to the Officiating Secretary to the Government of India, $8^{\text {th }}$ July, 1853, Foreign Proceedings No, $185-186,9^{\text {th }}$ September.

9. Report of the Administration of the Punjab Proper for the year 1849-50 \& 185051, p: 65.

10. Chhabra GS (1962) Social and Economic History of the Punjab 1849-1901, Sterling Publishers, New Delhi, p: 81.

11. District Gazetteer, Ferozepur, 1915, p: 70

12. Montgomery R (1853) Minute on Infanticide in Punjab, Foreign Proceedings No, $86-90,9^{\text {th }}$ September.

13. Punjab Census Report, 192. I: 227.

14. Chhabra GS, Opt. cit, p: 82.

15. Census Report, 1881, p: 367.

16. Census Report (1891) p: 200

17. Punjab Census Report (1901) Part I p: 127.

18. Edwardes SM (1968) Crime in India p: 3.

19. Melville $P$ (1853) Secretary to the Chief Commissioner to the Officiating Secretary to the Government of India. Foreign Proceedings No. 185-186.

20. Grant JP (1853) Officiating Secretary to the Government of India to John Lawrence. Foreign Proceedings No. 186-187, 9 $^{\text {th }}$ September, 1853.

21. Browne C, Allen WH (1857) Female Infanticide, 133-134.

22. Grant JP (1853) Officiating Secretary to the Government of India to John Lawrence. Foreign Proceedings No.185-187, $9^{\text {th }}$ September, 1853

23. Foreign Miscellaneous Department Proceedings, Sr. No. 157 362-363.

24. Browne C Opt. cit., p: 144.
25. Census of India (1911) 1 p: 218.

26. District Gazetteer Ludhiana (1904) p: 82.

27. Report on the Administration of Police in Punjab for the year (1905) p: 6.

28. Report on the Administration of Police in Punjab for the year (1919) p: 6

29. Paisa Akhbar (1910) Lahore $22^{\text {nd }}$ August.

30. Report on the Administration of Police in Punjab for the year (1912) p: 18.

31. Report on the Administration of Police in Punjab for the year (1919) p: 6.

32. Report on the Administration of Police in Punjab for the year (1922) p: 7.

33. Report on the Administration of Police in Punjab for the year (1892) Extracts from the District Reports.

34. Report on the Administration of Police in Punjab for the year (1911) p: 14.

35. Report on the Administration of Police in Punjab for the year (1915) p: 10.

36. Report on the Administration of Police in Punjab for the year (1916) p: 11.

37. Report on the Administration of Police in Punjab for the year (1912) p: 5.

38. Report on the Administration of Police in Punjab for the year (1918) p: 5.

39. Census Report (1901) 216-217.

40. Edwardes SM Opt. cit, p: 70.

41. Ibid p: 73

42. Report on the Administration of Police in Punjab for the year (1917) p: 5.

43. Singh B (1981) "Condition of Women in the Punjab in the Early Nineteenth Century", The Punjab, Past and Present, XV: II (30), p: 361.

44. Grewal JS, Singh MR (1962) Department of History, Guru Nanak Dev University, Amritsar, p: 77.

45. Singh BV (1984) The Sixth River of Punjab, p: 189.

46. Nirankari MS, Baba Dyal Crusader of True Sikhism, p: 16.

47. Report on the Administration of Police in Punjab for the year (1905) p: 5. 